\title{
Factors affecting the occupational accident rates among nurses
}

\author{
Fatores que afetam as taxas de acidentes ocupacionais entre enfermeiros \\ Factores que afectan las tasas de accidentes ocupacionales entre enfermeros
}

How to cite this article:

Çelikkalp Ü, Dilek F. Factors affecting the occupational accident rates among nurses. Rev Esc Enferm USP. 2019;53:e03524. DOI: http://dx.doi.org/10.1590/ S1980-220X2018049703524

\section{(D) Ülfiye Çelikkalp ${ }^{1}$ \\ (D) Filiz Dilek ${ }^{2}$}

${ }^{1}$ Namik Kemal University, Health School Collage, Department of

Nursing, Tekirdag, Turkey.

${ }^{2}$ Namık Kemal University, Health Services Vocational School, Tekirdag, Turkey.

\begin{abstract}
Objective: In this hospital-based study, we aimed to determine occupational accident perceptions and occupational accident reasons in sample of Turkish nurses. Method: In the study, the Epworth Sleepiness Scale, the Workload Scale and a Study Questionnaire Form including the employment characteristics of the nurses, their socio demographic characteristics, and the occupational accidents they encountered. Results: 108 nurses (90 females, 18 males; mean age, $26.42 \pm 5.5$ years) participated in the study. $68.5 \%$ of nurses have undergone at least once a occupational accident. Most of the participants were found to have experienced occupational accidents with approximately half evaluating their occupational accidents risk as high. Most of the nurses worked overtime and in shifts. The mean total scores for the Epworth Sleepiness Scale and Workload Scale were respectively $9.09 \pm 3.33$ and $36.94 \pm 6.42$. Statistically significant differences in occupational accidents were found with regard to Epworth Sleepiness Scale and Workload Scale scores, working in shifts, and working overtime $(\mathrm{p}<0.05)$. Conclusion: It was concluded that nurses had very high rates of occupational accidents and that the heavy work conditions affected occupational accidents.
\end{abstract}

\section{DESCRIPTORS}

Accidents, Occupational; Nursing, Team; Sleep, Workload. 


\section{INTRODUCTION}

Health workers, who aim to provide health care services to the society, constitute a group with very high risk of exposure to occupational accidents because of the risks in their work environment ${ }^{(1)}$. In the year 2011, United States of America (USA) Department of Labor Secretary Solis, defined the main source of workplace injuries as the health care industry and stated that the occupational accidents occurring in the field of health services were more frequent compared to other sectors ${ }^{(2)}$. According to 2013 data from the Employment Statistics Bureau, while a $19.2 \%$ rate of injury was reported for nurses in public institutions, the same rate was $3.7 \%$ in other sectors ${ }^{(3)}$. According to literature, occupational accidents occur the most among nurses compared to other health workers ${ }^{(4-6)}$. Nurses, who work at hospitals and provide patient care 24 hours a day, are usually expected to maintain optimal job performance. However, most nurses working at hospitals face difficult working conditions such as personnel shortage, excessive workloads, working in shifts, working at night, circadian changes, and overtime ${ }^{(7)}$. Especially the physical and mental burnout developed through these working conditions may cause negative outcomes in relation to employee safety ${ }^{(7-8)}$. This is known to increase the occupational disease, occupational accident, work related health problem, injury, and incapacity rates of health workers as well as creating new situations and increasing the variety of such problems ${ }^{(4)}$.

In the literature, it has been stated that occupational accidents are seen more especially in nurses working in shifts, with problems such as sleep disorders, gastrointestinal system disorders, and depression ${ }^{(7,9)}$. In a study including 10,793 people from the USA, exhibited that, after standardizing for age, gender, occupation, area of residence, and sector of employment, those who worked overtime had a $61 \%$ higher risk of occupational accidents compared to those who did not, and that working 12 hours a day increased the risk by $37 \%{ }^{(10)}$. In a study conducted in Japan, working in varying shifts disrupted the mental health of nurses, increasing the risks of occupational accidents and medical errors ${ }^{(11)}$.

Health workers losing their health, being disabled, or being exposed to loss of income because of exposure to occupational accidents tied to occupational risks and dangers have humanitarian, social, psychological, and economic importance ${ }^{(12)}$. Although the reasons behind occupational accidents and under which conditions they occur more are not fully known, the reporting processes of these accidents are also not executed fully. Since sufficient legal regulations and applications do not exist on the subject in Turkey, the determination of the full extent of the problem is difficult. Data regarding under which conditions health personnel who experience occupational accidents live, how many people become incapacitated, or how many are injured or deceased cannot be fully attained. There are no scientific studies representing the whole of Turkey, and the omissions in the reports also draw attention. Alongside this, not knowing the reasons behind the accidents is an important obstacle before the formation of protective measures. All of these show that occupational accidents in the health sector constitute an important public health issue that has to be studied and planned for because of the losses they cause. In this context, this study aimed to determine the occupational accident related perceptions of nurses working at a university hospital and to evaluate the occupational accidents that the nurses stated they underwent. Additionally, whether certain employment characteristics of the nurses or their status regarding workloads and sleep had any effect on occupational accidents was evaluated.

\section{METHOD}

\section{TYPE OF STUDY}

The study is a cross-sectional descriptive study. This was a hospital-based survey performed on all nurses working in various clinics of the hospital between March and June 2016.

\section{Population}

The study population included 152 nurses working in health services of health practice and research center. No sampling method was implemented in the present study. All the study population was intended to be included in the study. Of the study population, 108 health workers volunteered to participate in the research. The participation rate was $71 \%$.

\section{Data collection}

Each participant was asked to complete three questionnaires. The first one was the Study Questionnaire Form that was designed by the study team to collect data on participants' sociodemographics and working features and occupational accident in clinical nursing practice. This questionnaire contains 20 multiple-choice or open-ended questions, and a 4-point visual analog scale, which scores participants' thoughts on the importance of occupational accident in the scope of nursing practice in which 1 corresponds to "no risk" and 4, corresponds to "higt risk".

Second, the Workload Scale (WS) developed in 1994 by Duxbury and Higgins was used. The scale is a 5 way Likert type tool with 11 items aiming to determine the time, information, skill, responsibility, workload, and perceived workload necessary to perform the job (1= I certainly disagree, $5=\mathrm{I}$ certainly agree). The minimum score that can be attained from the scale is 11 and the maximum is 55 . As scores increase, the perceived workload increases and this shows that the individual cannot tolerate the job well enough. The validity and reliability study for the scale in Turkish was performed by Aycan and Eskin in 2005 ${ }^{(13)}$.

Third, the 8 item Epworth Sleepiness Scale (ESS) developed by Johns in 1991 was used. This is a practical scale that 
is easy to apply and evaluate and is used widely. The ESS is a four way Likert type scale scored as $0,1,2$, or 3 with higher scores showing sleepiness. It is among the self-reported scales developed for the qualitative and quantitative assessment of sleepiness. Contrary to other self-reported scales, this scale aims to measure the general level of daytime sleepiness instead of evaluating sleepiness for daily special conditions and specific time periods. The Turkish validity and reliability study of the ESS was performed by Ağargün et al. $(1999)^{(14)}$. In the scale, which has a minimum score of 0 and a maximum of 24 , excessive daytime sleepiness and circadian rhythm changes can be pronounced in people who reach more than 10 points.

\section{DATA ANALYSIS AND PROCESSING}

The data was analyzed using the SPSS 16.0 program and summarized with descriptive statistics (frequency, percentage, mean, standard deviation, and range) and comparative statistics methods (Chi-square Test, Independent Samples T-Test, Kruskal-Wallis Test). Statistical evaluations were carried out in 95\% confidence interval and bilateral assessment. Statistical level of significance level was set to $\mathrm{p}<0.05$.

\section{ETHICAL ASPECTS}

To carry out the research, written permissions were obtained from the ethics committee of the university (4 June 2015; number 2015/54) where the study was to be conducted and the directorate of health practice and research center. The participants gave their verbal consent after they were informed about the research. The participants filled out the questionnaires in the health centers where they worked. It took each participant approximately 15 minutes to complete the questionnaire.

\section{RESULTS}

\section{Characteristics OF STUDY PARTICIPANTS ACCORDING TO RESPONSES TO STUDY QUESTIONNAIRE}

The mean age of the nurses in the study group was $26.42 \pm 5.53$. A large majority of the participants were female $(83.3 \%)$ and had bachelor's degrees (56.5\%). When the employment characteristics of the nurses in the study group were examined, $39.8 \%$ worked in intensive care or surgery services, more than half $(64.8 \%)$ had less than 5 years of experience, and the mean occupational experience duration was found to be $59.12 \pm 60.34$ months. $70.4 \%$ of the participants worked in shifts and $81.5 \%$ worked overtime. The mean weekly work duration of the nurses was $47.30 \pm 4.67$ hours with a mean of 3 weekly night shifts.

It was determined that $65.7 \%$ of the nurses in the study group had a desire to sleep during the day, with $13.8 \%$ having sleeplessness and $18.5 \%$ having a snoring problem. The mean daily sleep duration of the nurses was $7.09 \pm 1.35$ hours and their mean ESS total score was 9.09 \pm 3.33 , (Table 1).
Table 1 - Sociodemographics and basic characteristics of study participants according to responses to study questionnaire Tekirdağ, Turkey, 2016-2017.

\begin{tabular}{|c|c|c|}
\hline Characteristics & $\mathbf{n}$ & $\% /$ Mean $\pm S D^{*}$ \\
\hline \multicolumn{3}{|l|}{ Gender } \\
\hline Female & 90 & 83.3 \\
\hline Male & 18 & 16.7 \\
\hline \multicolumn{3}{|l|}{ Education level } \\
\hline Medical Vocational School & 24 & 22.2 \\
\hline Associate degree & 14 & 13.0 \\
\hline Bachelor degree & 61 & 56.5 \\
\hline Postgraduate & 9 & 8.3 \\
\hline \multicolumn{3}{|l|}{ Clinic of employment } \\
\hline Surgical & 41 & 38.0 \\
\hline Internal diseases & 24 & 22.2 \\
\hline Intensive care/operating room & 43 & 39.8 \\
\hline \multicolumn{3}{|l|}{ Working year } \\
\hline Less than 5 years & 70 & 64.8 \\
\hline More than 5 years & 38 & 35.2 \\
\hline \multicolumn{3}{|l|}{ Shift Work } \\
\hline Yes & 76 & 70.4 \\
\hline No & 32 & 29.6 \\
\hline \multicolumn{3}{|l|}{ Overtime } \\
\hline Yes & 88 & 81.5 \\
\hline No & 20 & 18.5 \\
\hline \multicolumn{3}{|l|}{ Insomnia problem } \\
\hline Yes & 15 & 13.8 \\
\hline No & 97 & 86.8 \\
\hline \multicolumn{3}{|l|}{ Snore } \\
\hline Yes & 20 & 18.5 \\
\hline No & 88 & 81.5 \\
\hline \multicolumn{3}{|l|}{ Daytime sleep request } \\
\hline Yes & 71 & 65.7 \\
\hline No & 37 & 34.3 \\
\hline Number of weekly seizures (median) & & 3 \\
\hline Average weekly working time (hours/week) & & $47.30 \pm 4.67$ \\
\hline Daily average sleep time (hours) & & $7.09 \pm 1.35$ \\
\hline WS & & $36.94 \pm 6.42$ \\
\hline ESS & & $9.09 \pm 3.33$ \\
\hline
\end{tabular}

*Mean \pm SD: mean \pm standard deviation.

\section{Occupational Accidents}

$68.5 \%$ of the nurses who participated in the study were found to have experienced at least 1 occupational accident during their professional life. Alongside this, $31.5 \%$ of the nurses have experienced at least one occupational accident within the last six months and $15.7 \%$ have experienced such an accident within the last week. The most common accident was injector tip wounds, followed by occurrences of violence. Only a third (35.1\%) of the nurses who experienced occupational accidents reported them (Table 2). 
Table 2 - Characteristics of nurses' occupational accidents Tekirdağ, Turkey, 2016-2017.

\begin{tabular}{|c|c|c|}
\hline Characteristics & $\mathbf{N}$ & $\%$ \\
\hline \multicolumn{3}{|l|}{ Occupational accident } \\
\hline Yes & 74 & 68.5 \\
\hline No & 34 & 31.5 \\
\hline \multicolumn{3}{|l|}{ In the last 6 months } \\
\hline Yes & 28 & 25.9 \\
\hline No & 80 & 74.1 \\
\hline \multicolumn{3}{|l|}{ In the last week } \\
\hline Yes & 17 & 15.7 \\
\hline No & 91 & 84.3 \\
\hline \multicolumn{3}{|l|}{ Type of occupational accident * } \\
\hline Needlesticks & $78^{*}$ & $55.8^{*}$ \\
\hline Violence & 45 & 32.1 \\
\hline Slip and falls & 12 & 8.6 \\
\hline Musculoskeletal discomfort while lifting patients & 15 & 10.7 \\
\hline Traffic accident & 1 & 0.7 \\
\hline \multicolumn{3}{|l|}{ Reported a occupational accident } \\
\hline Yes & 26 & 35.1 \\
\hline No & 48 & 64.9 \\
\hline \multicolumn{3}{|l|}{ Occupational accident risk } \\
\hline No risk & 1 & 0.9 \\
\hline Low risk & 8 & 7.4 \\
\hline Moderate risk & 39 & 36.1 \\
\hline High risk & 60 & 55.6 \\
\hline
\end{tabular}

*percentage in occupational accident.

Alongside this, more than half of the nurses $(55.6 \%$, $\mathrm{n}=60$ ) evaluated the occupational accident risk in their work environment as high (Table 2). When the occupational accidents experienced by the nurses were compared to certain demographic and occupational characteristics, the occupational accident rate in the group working in shifts was found to be higher with a statistically significant difference $\left(\chi^{2}=5.300, p<0.05\right)$. There was no statistically significant difference between occupational accidents and gender, age, years of employment, and service ( $p>0.05)$, (Table 3$)$.

Table 3 - Determinants of occupational accidents in the last 6 months - Tekirdağ, Turkey, 2016-2017.

\begin{tabular}{|c|c|c|c|c|c|}
\hline \multirow{3}{*}{ Variables } & \multicolumn{4}{|c|}{ In the last 6 months } & \multirow{3}{*}{$\mathbf{p}^{*}$} \\
\hline & \multicolumn{2}{|c|}{ Yes } & \multicolumn{2}{|c|}{ No } & \\
\hline & $n$ & $\%$ & $\mathrm{n}$ & $\%$ & \\
\hline \multicolumn{6}{|l|}{ Gender } \\
\hline Female & 27 & 30.0 & 63 & 70.0 & \multirow{2}{*}{$\begin{array}{l}0.549 \\
0.459\end{array}$} \\
\hline Male & 7 & 38.9 & 11 & 61.9 & \\
\hline \multicolumn{6}{|l|}{ Age group } \\
\hline 19-22 years & 14 & 41.2 & 20 & 58.8 & \multirow{4}{*}{$\begin{array}{l}3.114 \\
0.37\end{array}$} \\
\hline 23-26 years & 10 & 33.3 & 20 & 66.7 & \\
\hline $27-30$ years & 5 & 21.7 & 18 & 78.3 & \\
\hline 31 and $\uparrow$ & 5 & 23.8 & 6 & 76.2 & \\
\hline \multicolumn{6}{|l|}{ Working years } \\
\hline Less than 5 years & 25 & 35.7 & 45 & 64.3 & \multirow{2}{*}{$\begin{array}{l}1.652 \\
0.142\end{array}$} \\
\hline More than 5 years & 9 & 23.7 & 29 & 76.3 & \\
\hline \multicolumn{6}{|l|}{ Shift work } \\
\hline Yes & 29 & 38.2 & 47 & 61.8 & \multirow{2}{*}{$\begin{array}{l}5.300 \\
\mathbf{0 . 0 1 6}\end{array}$} \\
\hline No & 5 & 84.4 & 27 & 15.6 & \\
\hline \multicolumn{6}{|l|}{ Clinic of employment } \\
\hline Surgical & 12 & 29.3 & 19 & 70.7 & \multirow{3}{*}{$\begin{array}{l}2.648 \\
0.266\end{array}$} \\
\hline Internal diseases & 5 & 20.8 & 19 & 29.2 & \\
\hline Intensive care/operating room & 17 & 39.5 & 26 & 60.5 & \\
\hline
\end{tabular}

${ }^{*} \mathrm{p}<0.05$. Chi-square test.

\section{WS AND ESS SCORES}

The mean total Workload Scale score of the participants was 36.94 \pm 6.42 . One of the important findings of this study was the statistically significant difference between the WS mean scores of the study group and their status regarding experiencing occupational accidents $(\mathrm{p}<0.05)$. Accordingly, the WS mean score of the nurses who experienced occupational accidents was higher. Another interesting result is that although a difference was perceived between mean total WS scores and age group $(\mathrm{p}<0.05)$, no significant difference between WS scores and gender, years of employment, and service could be found (Table 4).

Statistically significant differences between the ESS mean scores of the nurses and their age, status regarding working in shifts, years of employment, and status regarding experiencing occupational accidents were found $(\mathrm{p}<0.05)$. ESS scores were considered significantly higher in nurses working in shifts compared to those that did not. There was no statistically significant difference between ESS mean scores with regard to gender and service $(p>0.05)$ (Table 4$)$.

Table 4 - Comparison of Epworth Sleepiness Scale and Workload Scale mean scores by characteristics of nurses - Tekirdağ, Turkey, 2016-2017.

\begin{tabular}{|c|c|c|}
\hline Characteristics & Workload Scale & Epworth Sleepiness Scale \\
\hline Gender & Mean $\pm \mathrm{SD}^{*}$ & Mean $\pm \mathrm{SD}^{*}$ \\
\hline Female & $37.10 \pm 6.36^{*}$ & $8.97 \pm 3.49 *$ \\
\hline Male & $36.16 \pm 6.87$ & $9.66 \pm 2.42$ \\
\hline $\mathrm{t}$ & $0.561^{* *}$ & $-0.798^{* *}$ \\
\hline $\mathrm{p}$ & 0.576 & 0.427 \\
\hline \multicolumn{3}{|l|}{ Age group $* * *$} \\
\hline 19-22 years & $35(19-49)$ & $10(1-20)$ \\
\hline $23-26$ years & $40(24-49)$ & $10(3-14)$ \\
\hline $27-30$ years & $38(23-55)$ & $9(3-15)$ \\
\hline 31 and $\uparrow$ & $37(23-46)$ & $8(2-12)$ \\
\hline KW test & $10.702^{* * * *}$ & $10.484^{* * * *}$ \\
\hline $\mathrm{p}$ & 0.013 & 0.015 \\
\hline \multicolumn{3}{|l|}{ Working years } \\
\hline Less than 5 years & $37.11 \pm 6.50$ & $9.72 \pm 3.25$ \\
\hline More than 5 years & $36.63 \pm 6.35$ & $7.92 \pm 3.21$ \\
\hline $\mathrm{t}$ & $0.371^{* *}$ & $2,769^{* *}$ \\
\hline $\mathrm{p}$ & 0.711 & 0.007 \\
\hline \multicolumn{3}{|l|}{ Shift work } \\
\hline Yes & $37.60 \pm 6.86$ & $9.60 \pm 2.93$ \\
\hline No & $36.81 \pm 6.26$ & $7.87 \pm 3.93$ \\
\hline $\mathrm{t}$ & $-0.138^{* *}$ & $-2.520^{* *}$ \\
\hline $\mathrm{p}$ & 0.891 & 0.013 \\
\hline \multicolumn{3}{|l|}{ Clinic of employment ${ }^{* * *}$} \\
\hline Surgical & $37(19-55)$ & $10(2-16)$ \\
\hline Internal diseases & $35(23-46)$ & $8(2-20)$ \\
\hline $\begin{array}{l}\text { Intensive } \\
\text { care/operating room }\end{array}$ & $37(24-49)$ & $10(1-14)$ \\
\hline KW test & $2.037^{* * * *}$ & $4.305^{* * * *}$ \\
\hline $\mathrm{p}$ & 0.361 & 0.116 \\
\hline \multicolumn{3}{|l|}{ Occupational accident } \\
\hline Yes & $38.00 \pm 5.95$ & $9.86 \pm 3.70$ \\
\hline No & $34.64 \pm 6.90$ & $8.01 \pm 3.18$ \\
\hline $\mathrm{t}$ & $-2.584^{* *}$ & $-2.662^{* *}$ \\
\hline $\mathrm{p}$ & 0.011 & 0.041 \\
\hline \multicolumn{3}{|c|}{$\begin{array}{l}{ }^{*} \text { Mean } \pm \text { SD: mean } \pm \text { standard deviation, }{ }^{* *} \text { Student- } t \text { test, } \\
{ }^{* * *} \text { Values for continuous variables median (minimum-maximum) } \\
{ }^{* * * *} \text { KW: Kruskal Wallis variance analysis. }\end{array}$} \\
\hline
\end{tabular}




\section{DISCUSSION}

\section{ACCIDENT TYPES}

In this descriptive study performed to determine both the rate of occupational accidents experienced by the nurses working at a university hospital and the reasons behind those accidents, a large majority (68.5\%) of the nurses have experienced at least one occupational accident. The most common occupational accident was injector tip wounds, followed by violence, slipping, and falling. Additionally, a quarter of the nurses have experienced an occupational accident within the last six months and $15.9 \%$ have experienced such an accident within the last week. In a study conducted in India with health workers, mucous membrane exposure was reported to be $11 \%$ in only a week with $70 \%$ of percutaneous injuries not being reported at all, and these findings were considered alarming ${ }^{(15)}$.In similar studies conducted in Turkey and abroad, injector tip wounds remained the most frequent type of accident ${ }^{(12,16)}$. According to data from The Center for Disease Control and Prevention, injector tip and percutaneous injuries increase every year among health workers in the USA, with 800 thousand yearly injector injuries and a mean daily 1,000 puncturing tool injuries reported. Additionally, in compliance with the findings of the present study, $60 \%$ of puncturing tool injuries were stated to be unreported ${ }^{(16)}$. The results are important with regard to showing that especially injector tip wounds are very frequent among nurses and that protective and preventive measures should be taken.

According to the Occupational Health and Safety Law numbered 6331 in Turkey violence is defined as events that occur at the workplace within working hours and while working that cause physical or mental injury (Occupational Law No: 6331$)^{(17)}$. For this reason, cases of violence are accepted to be occupational accidents just like in the USA and Europe ${ }^{(18)}$.In recent years, a serious increase in cases of violence against health workers has been seen worldwide ${ }^{(19)}$. In the present study, a third of the nurses were exposed to violence by patients or their relatives. In the literature, in studies performed to determine the rates of violence experienced by nurses at the workplace, the rates of exposure vary between $27.5 \%$ and $90 \%{ }^{(18,20)}$. In a study conducted in the USA, it was stressed that $76 \%$ of nurses were exposed to violence within the last year, and that legal regulations should be made to prevent these cases of violence ${ }^{(20)}$. Even though the results of the studies vary, it is important to show the importance of the problem and that such violence is seen in every society. Moreover, both national and international efforts are needed to remove violence.

In a study performed in a university hospital in Ankara, Turkey, the participants reported slipping and falling as the second most frequent occupational accident type in a manner differing from this study ${ }^{(12)}$. Meanwhile regarding the occupational accidents in the hospitals in the USA with at least one workday lost in the last year, the most reported accidents were musculoskeletal system difficulties (48\%), slipping and falling (25\%), contact with a puncturing tool $(13 \%)$, violence $(9 \%)$, and exposure to chemicals $(4 \%)^{(18)}$. In the present hospital, the most frequent occupational accident types regarding the number of people having accidents within the last year were reported to be puncturing tool injuries (55.8\%), violence (32.1\%), musculoskeletal system difficulties (10.7\%), and slipping and falling (8.6\%). Slipping and falling rates as well as musculoskeletal system difficulties have lower rates compared to examples in both Turkey and the world. However, these are the accidents that cause the most loss of workdays in the USA. The reason behind this difference may be heavy lifting, mostly performed by cleaning personnel and whose work was not included in the study since their workplace health department is different; or the fact that workers do not take musculoskeletal complaints seriously until they become chronic.

\section{Employment Conditions and Occupational Accidents}

When the employment characteristics of the nurses were examined, very interesting findings were reached. A large majority of the nurses worked in 16 hour shifts, worked over 45 hours a week, and worked in a mean value of 3 night shifts a week. In a study conducted in the US, $79 \%$ of the nurses worked in 12 hour shifts, and $41.1 \%$ worked over 40 hours a week ${ }^{(21)}$. A study conducted in two hospitals in US, found that $15.6 \%$ of the nurses worked more than 40 hours a week ${ }^{(22)}$.In a study performed in Thailand, the nurses were reported to usually work over 40 hours a week under heavy working conditions ${ }^{(23)}$. Although there are studies in compliance with the present one ${ }^{(12,23)}$,there are also studies that contradict this study ${ }^{(21-22)}$. The reason behind the weekly working hours is thought to be the difference between the legal regulations pertaining to the work life of each country and the number of nurses employed. In Turkey, although the weekly work hour legal limit is 45 hours (Occupational Law No: 6331), this number is between 35 and 40 in most countries. Also, while 183 nurses serve every 100 thousand people in Turkey, this number is 909 for every 100 thousand people in OECD countries ${ }^{(24)}$. These findings show that the number of nurses in Turkey is insufficient and employment conditions can thus be difficult. A lower number of personnel means greater workloads and more work hours. However, this may increase physical and cognitive load and cause many health problems and occupational accidents.

Indeed, a significant relationship between employment conditions and status regarding experiencing occupational accidents has been reported in the literature $e^{(7,21,25)}$. In the present study, while the occupational accident rate within the last six months was $38.2 \%$ in the group only working during daytime, the injury rate in the group working in shifts was higher (84.4\%). In a study conducted in US, injury rates were found to be higher in nurses who worked in night shifts and those with greater weekly work hours ${ }^{(21)}$. In Mongolia, the rate of puncturing tool injuries was 2.5 times greater in health workers who worked more than 35 hours a week ${ }^{(25)}$. The risk of puncturing tool related occupational accidents were shown to increase alongside weekly work hours among nurses in Iran ${ }^{(26)}$. The present results are parallel to many studies. However, the employment conditions of nurses in Turkey are really heavy. When nurses working overtime in 
16 hour shifts with an average of 3 night shifts a week are considered, the high rate of occupational accidents is not surprising. It is very natural to experience intense cumulative fatigue under such continuous heavy employment conditions.

In this study, the occupational accident rates of the nurses with higher WS mean scores were greater. Considering the small number of nurses in Turkey, this excess workload is expected. It can be said that increased workloads and heavy employment conditions affect nurses both physically and psychologically, and that the cumulative fatigue increases the probability of accidents. Alongside this, the fact that the occupational accidents experienced by the nurses did not significantly differ according to variables such as gender, age group, occupational experience, and service strengthen the claim that occupational accidents are related to employment conditions and workloads. Thus, all employees can be stated to be similar with regard to employment conditions.

One of the most important findings of the study is the $55.6 \%$ rate of perceiving the risk of occupational accidents in the work environment as high. However, when it is considered that $68.5 \%$ of the nurses had previously experienced occupational accidents, this also shows that the awareness of the participants on occupational accidents in the work environment was low.

\section{Sleep Status and Occupational Accidents}

Although the daily sleep durations of the participants, who had difficult employment conditions, seemed sufficient, the fact that a large majority (65.7\%) had a desire to sleep during the day can be seen as an important problem. Excessive daytime sleepiness is another important symptom of sleep disorders ${ }^{(9)}$.The Epworth Sleepiness Scale is a subjective tool for measuring sleepiness. In the literature, insufficient sleep durations caused by working in shifts and circadian rhythm disorders have been reported to cause excessive daytime sleepiness ${ }^{(7)}$. In two similar studies, sleeplessness problems in nurses working in night shifts was reported ${ }^{(27)}$, while the inclination for sleep during work was found to be greater in workers working in shifts compared to those who worked during the day ${ }^{(9)}$. In this study, the ESS scores were higher in the nurses working in shifts. However, despite not being over the cut point of 10, the mean ESS score above 9 suggested that the nurses were under risk in relation to daytime sleep problems and circadian shifts.

The incidence of occupational accidents and other accident types increases as a result of sleeplessness and sleep related disorders. The sleepiness seen in those who work in shifts has been reported to increase the risk of accidents ${ }^{(7,9)}$. A study conducted in Sweden stressed that excessive daytime sleepiness was related to occupational accidents, determined working in shifts as an independent risk factor for occupational accidents, and revealed the risk of occupational accidents to be 2.2 times greater in those with snoring problems ${ }^{(28)}$. A study conducted in Japan stressed that excessive daytime sleepiness was related to occupational accidents in nurses working in shifts, and showed that the daytime sleepiness rate among nurses was $26 \%$, and that events such as erroneous drug administration, erroneous operation tool selection, and injector injuries were significantly more frequent in those who often or constantly had sleepiness symptoms ${ }^{(11)}$. In this study, $38.2 \%$ of the nurses who worked in shifts have experienced an occupational accident within the last six months, and mean ESS scores were considered to be significantly higher in nurses who had occupational accidents.

In this study, the ESS mean score of the nurses in the younger age group with less than 5 years of experience was found to be above 10. The higher mean ESS score of the younger nurses is an important problem with regard to suggesting daytime sleepiness and other sleep problems. A more comprehensive study on the subject to question sleep disorders and evaluate the necessary cases with polysomnography is required. However, the most significant findings on the subject in younger nurses are caused by newly graduated nurses mostly being assigned to intensive care services, working in additional shifts, and working overtime.

\section{CONCLUSION}

In conclusion, in this nurse-based surveillance study, most of the nurses experienced occupational accidents despite their low perception of occupational accidents and there was a significant difference between occupational accidents with regard to employment conditions (working in shifts, working at night, overtime, and workload). Additionally, it was found that employment conditions affected negatively the sleep quality of the nurses and that those who had occupational accidents had higher mean ESS scores. Each year many nurses lose their health or life to occupational accidents. Knowing the reasons behind the occupational accidents experienced by nurses has an important place in decreasing occupational accidents. Despite a population of 81 million and 135,000 employed nurses, there are a limited number of studies in Turkey regarding the reasons behind the occupational accidents experienced by nurses. Thus, this study is important with regard to contributing to the determination of the reasons behind the occupational accidents experienced by nurses.

Alongside this, when the heavy work conditions and workloads of the nurses are considered, increasing the number of nurses seems to be the solution to many problems. Through the use of clinic specific patient classification systems, the number of nurses required for services should be determined and sufficient employment should be achieved. In order to decrease occupational accidents among nurses in Turkey, the employment conditions of nurses should be improved, the number of employed nurses should be increased, the awareness of nurses on occupational accidents should be enlarged, and protective applications should be given more importance. The occupational accidents that nurses are exposed to should be evaluated within the context of a record system and record keeping should be prioritized. Data from the present study and similar studies would contribute greatly to the formation of the appropriate employment conditions to protect nurses from occupational accidents and to the development of relevant regulations. 
RESUMO

Objetivo: Neste estudo com base hospitalar, pretendemos determinar as percepções e razões dos acidentes ocupacionais numa mostra de enfermeiros turcos. Método: No estudo, foram utilizados a Escala de Sonolência de Epworth, a Escala de Carga de Trabalho e um Formulário com Questionário de Estudo, incluindo as características sociodemográficas e os acidentes ocupacionais que encontraram. Resultados: 108 enfermeiros (90 do sexo feminino, 18 do sexo masculino; idade média, 26,42 $\pm 5,5$ anos) participaram do estudo; 68,5\% dos enfermeiros passaram por, pelo menos, um acidente ocupacional. Foi observado que a maioria dos participantes sofreu acidentes ocupacionais, com aproximadamente a metade avaliando seu acidente ocupacional como de alto risco. A maioria dos enfermeiros fazia hora extra e trabalhava em turnos. Os principais scores totais para a Escala de Sonolência de Epworth e a Escala de Carga de Trabalho foram respectivamente $9,09 \pm 3,3$ e 36,94 $\pm 6,42$. Foram encontradas diferenças estatisticamente significativas com relação à Escala de Sonolência de Epworth e aos scores da Escala de Carga de Trabalho, trabalho em turnos e horas extras ( $\mathrm{p}<0,05)$. Conclusão: Foi concluído que os enfermeiros tiveram taxas muito altas de acidentes ocupacionais e que as duras condições de trabalho afetaram os acidentes ocupacionais.

\section{DESCRITORES}

Acidentes de Trabalho; Equipe de Enfermagem; Sono; Carga de Trabalho.

\section{RESUMEN}

Objetivo: En este estudio con base hospitalaria, pretendemos determinar las percepciones y razones de los accidentes ocupacionales en una muestra de enfermeros turcos. Método: En el estudio, fueron utilizados la Escala de Somnolencia de Epworth, la Escala de Carga Laboral y un Formulario con Cuestionario de Estudio, incluyéndose las características sociodemográficas y los accidentes ocupacionales que encontraron. Resultados: 108 enfermeros (90 del sexo femenino, 18 del sexo masculino; edad media, 26,42 $\pm 5,5$ años) participaron en el estudio; el 68,5\% de los enfermeros pasaron por al menos un accidente ocupacional. Se observó que la mayoría de los participantes sufrieron accidentes ocupacionales, siendo que cerca de la mitad de ellos evaluaron su accidente ocupacional como de alto riesgo. La mayoría de los enfermeros hacían horas extraordinarias y trabajaban a turnos. Los principales scores totales para la Escala de Somnolencia de Epworth y la Escala de Carga Laboral fueron respectivamente 9,09 $\pm 3,3$ y 36,94 $\pm 6,42$. Fueron encontradas diferencias estadísticamente significativas con relación a la Escala de Somnolencia de Epworth y a los scores de la Escala de Carga Laboral, trabajo a turnos y horas extraordinarias $(p<0,05)$. Conclusión: Fue concluido que los enfermeros tuvieron tasas muy altas de accidentes ocupacionales y que las duras condiciones laborales afectaron los accidentes ocupacionales.

\section{DESCRIPTORES}

Accidentes de Trabajo; Grupo de Enfermería; Sueño; Carga de Trabajo.

\section{REFERENCES}

1. McCaughey D, Kimmel A, Savage G, Lukas T, Walsh E, Halbesleben J. Antecedents to workplace injury in the health care industry: a synthesis of the literature. Health Care Manage Rev. 2016;41(1):42-55.

2. United States Departament of Labor; Occupational Safety and Health Administration, Statement from Secretary of Labor Hilda L. Solis on reported decline in workplace injuries and illnesses [Internet]. Washington: OSHA; 2011 [cited 2018 Mar 17]. Available from: https://www.osha.gov/news/newsreleases/statement/10212010

3. United States Department of Labor. Bureau of Labor Statistics. Nonfatal occupational injuries and illnesses requiring days away from work, 2012 [Internet]. BLS; 2013 [cited 2018 Apr 11]. Available from: http://www.bls.gov/iif/

4. Davas A, Türk M, Yüksek M. The relationship between working conditions and work accidents: a hospital example. MSG. 2016;60-61:67-75

5. Ghannad MS, Majzoobi MM, Ghavim M, Mirzaei M. Needlestick and sharp object injuries among health care workers in Hamadan Province Iran. J Emerg Nurs. 2012;38 (2):171-5.

6. Liu X, Sun X, Genugten LV, Shi Y, Wang Y, Niu W, et al. Occupational exposure to blood and compliance with standard precautions among health care workers in Beijing, China. Am J Infect Control. 2014;42(3):e37-8.

7. Caruso CC. Negative impacts of shiftwork and long work hours. Rehabil Nurs. 2014;39(1):16-25.

8. Sagherian K, Clinton ME, Huijer HS, Geiger-Brown J. Fatigue, work schedules, and perceived performance in bedside care nurses. Workplace Health Saf. 2017;65(7): 304-12

9. Sönmez S, Ursavaş A, Uzaslan E, Ediger D, Karadağ M, Gözü RO, et al. Sleep disorders and occupational accident in shift work nurses. Chest J. 2014;146(4):947A.

10. Dembe AE, Erickson JB, Delbos RG, Banks SM. The impact of overtime and long work hours on occupational injuries and illnesses: new evidence from the United States. Occup Environ Med. 2005;62(9):588-97.

11. Suzuki K, Ohida T, Kaneita Y, Yokoyama E, Uchiyama M. Daytime sleepiness, sleep habits and occupational accidents among hospital nurses. J Adv Nurs. 2005;52(4):445-53.

12. Dikmen AU, Medeni V, Uslu I, Aycan S. Evaluation of occupational accidents by health personnel working in a university hospital in Ankara. MSG. 2014;53:2-29.

13. Aycan Z, Eskin M. Childcare, spousal, and organizational support in predicting work-family conflict for females and males in dual-earner families with preschool children. Sex Roles. 2005;53(7):453-71.

14. Ağargün MY, Çilli AS, Kara H, Bilici M, Telcioğlu M, Şemiz ÜB, et al. Validity and reliability of the epworth sleepiness scale. Turk Psikiyatri Derg. 1999;10(4):261-7.

15. Kermode M, Jolley D, Langkham B, Thomas MS, Crofts N. Occupational exposure to blood and risk of bloodborne virüs infection among health care workers in rural North Indian health care settings. Am J Infect Control. 2005;33(1):34-41.

16. Zhang X, Chen Y, Li Y, Hu J, Zhang C, Li Z, et al. Needlestick and sharps injuries among nursing students in Nanjing, China. Workplace Health Saf. 2018;66(6):276-84. 
17. Turkey. Ministry of Labour and Social Security. Occupational Law: 6331 [Internet] ÇSGB; 2012 [cited 2018 Feb 10]. Avaliable from: www.mevzuat.gov.tr/MevzuatMetin/1.5.6331.pdf

18. Gomaa AE, Tapp LC, Luckhaupt SE, Vanoli K, Sarmiento RF, Raudabaugh WM, et al. Occupational traumatic injuries among workers in health care facilities - United States, 2012-2014. MMWR Morb Mortal Wkly Rep 2015;64(15):405-10

19. Jiao M, Ning N, Li Y, GaoL, Cui Y, Sun H, et al. Workplace violence against nurses in Chinese hospitals: a cross-sectional survey. BMJ Open. 2015;5(3):e006719.

20. Speroni KG. Fitch T. Dawson E, Dugan L. Atherton M. Incidence and cost of nurse workplace violence perpetrated by hospital patients or patient visitors. J Emerg Nurs. 2014;40(3):218-28.

21. Stimpfel AW, Brewer CS, Kovner CT. Scheduling and shift work characteristics associatewith risk for occupational injury in newly licensed registered nurses: an observational study. Int J Nurs Stud. 2015;52(11):1686-93.

22. Bae SH. Presence of nurse mandatory overtime regulations and nurse and patient outcomes. Nurs Econ. 2013;31(2):59-68.

23. Kunaviktikul W, Wichaikhum O, Nantsupawat A, Nantsupawat R, Chontawan R, Klunklin A, et al. Nurses' extended work hours: patient, nurse, and organizational outcomes. Int Nurs Rev. 2015;62(3):386-93.

24. Bilir B, Yıldız AN. Occupational health and safety. Hacettepe Universty Press: Ankara; 2016.

25. Gholami A, Borji A, Lotfabadi P, Asghari A. Risk factors of needlestick and sharps injuries among healthcare workers. Int J Hosp Res. 2013;2(1):31-8.

26. Jahangiri M, Rostamabadi A, Hoboubi N, Tadayon, N, Soleimani A. Needlestick injuries and their related safety measures among nurses in a university hospital, Shiraz, Iran. Saf Health Work. 2016;7(1):72-7.

27. Brown JG, Sagherian K, Zhu S, Wieroniey M, Blair L, Warren J, et al. Napping on the night shift: a two-hospital implementation project. Am J Nurs. 2016;116(5):26-33.

28. Lindberg E, Carter N, Gislason T, Janson C. Role of snoring and daytime sleepiness in occupational accidents. Am J Respir Crit Care Med. 2001;164(11):2031-5. 